\title{
Pankkien syvin ongelma
}

Lena Rethel \& Timothy Sinclair:The problem with banks. Zed books, Lontoo 2012.

\section{Teppo Eskelinen}

Talouskriisin aikoina pankeista on puhuttu paljon. Keskustelun teemana on toisinaan pankkien pelastaminen, joskus rahoitusjärjestelmän reformit, joskus taas Occupy Wall Streetin kaltaiset protestiliikkeet.

Pankkeja analysoidaan kuitenkin hämmentävän vähän yhteiskunnallisina instituutioina. Puhe pankeista on useimmiten joko rahoitustaloustiedettä, jossa pakkien institutionaalisuus kadotetaan, tai niiden tarpeetonta psykologisointia, jolloin pankkeja syytetään "ahneudesta" tai "holtittomuudesta". Pankit eivät kuitenkaan noudata tällaisia psykologisia motiiveja, vaikka toki niiden toimintaan voi sisältyä - ja hyvin usein sisältyykin - kieroutuneita kannustimia.

Pankkijärjestelmän reformivaatimuksia toki esitetään. Toisinaan ne ovat hyvinkin lennokkaita, toisinaan masentavan mitäänsanomattomia. Toteutetut reformit ovat edenneet suhteellisen suljetuissa piireissä ja sisällöltään ne ovat olleet monille pettymyksiä

Systemaattisempi poliittisen talouden kirjallisuus pankeista yhteiskunnallisina instituutioina ja niiden mahdollisista tulevaisuuksista tuntuukin kiinnostavalta. Warwickin yliopiston Lena Rethel ja Timothy Sinclair ovat oivallisia tutkijoita tiivistämään tätä teemaa. Heidän kirjansa The problem with banks onnistuu tehtävässään, ainakin osittain. Kirja säilyttää hyvin fokuksensa. Rethel ja Sinclair kirjoittavat nimenomaan pankeista eivät rahapolitiikasta, asuntoluotoista, pankkiireista tai muusta sivuavasta aiheesta, johon olisi kyllä sinänsä kiinnostavaa ja houkuttelevaa päätyä. Mitä pankit ovat ja miksi, ja mitä ne voisivat olla?

Kirjalla on kaksi olennaista lähtökohtaa. Ensimmäinen on ajatus pankeista eri aikaperspektiivien välisten ristiriitojen hallinnointijärjestelminä. Pankkien myöntämä lainaraha on pitkälle tulevaisuuteen kohteeseensa sidottua, siinä missä vastaanotetut talletukset ovat ainakin potentiaalisesti lyhytaikaisia - ne voidaan nostaa koska tahansa. Pankkien toiminta ja uhat rakentuvat siis tämän aikaperspektiivien ristiriidan hallinnan ympärille. Tämä on 
toki hyvin yksinkertainen oppikirjamalli, mutta sen avulla voidaan hyvin selittää esimerkiksi joitakin pankkien muutospaineita.

Toinen lähtökohta on, että rahoituksen sääntely on ymmärrettävä konstituoivaksi eikä ainoastaan ulkopuoliseksi puuttumiseksi. Tämä poliittisen talouden näkökulma on tärkeää ottaa pankkien analysoinnin pohjaksi: valtio ja sääntelyjärjestelmät luovat pankit tietynlaisiksi. Sääntely siis määrittää, mitä pankit ovat, eikä ainoastaan anna puitteita niiden toiminnalle.

Tätä ideaa pankkien sääntelyn merkityksestä voi havainnollistaa John Searlen kuuluisaksi tekemällä, alun perin John Rawlsin esittämällä sääntöjen typologialla (Searle 1969; Rawls 1955). Searle jakaa säännöt "regulatiivisiin" ja "konstitutiivisiin". Regulatiivinen sääntö on toiminnan ulkoinen rajoite. Esimerkiksi liikennesännöt ovat regulatiivisia: ne rajoittavat toimintaa, jossa muuten tapahtuisi helposti ylilyöntejä. Konstitutiivinen sääntö taas merkitsee, että itse toiminta on riippuvainen säännön olemassaolosta. Esimerkiksi shakinpeluu on mahdollista vasta kun shakin säännöt on määritelty.

Kirjoittajien keskeinen ohjelmallinen väite on, että pankkien sääntely tulisi ymmärtää konstitutiivisen sääntökäsityksen näkökulmasta. Sääntelykehikko toisin sanoen luo pankit sellaisena kuin ne ovat - niiden institutionaalisen muodon, prioriteetit ja toimintalogiikan. Samasta syystä pankit eivät vain "pakene" sääntelypyrkimyksiä.

Tämä on kiinnostava metodologinen lähtökohta, sillä sekä tiukemman että väljemmän regulaation kannattajat tuntuvat usein jakavan ajatuksen rahoitusmarkkinoiden sääntelystä "regulatiivisina sääntöinä". Lähes yksimielisyys vallitsee siitä, että pankit ovat aina sääntelyä "edellä", vaikka osa vetääkin tästä sen johtopäätöksen, että pankkien sääntely on hyödytöntä ja toiset esittävät entistä päättäväisempää sääntelyä. Johtopäätökset ovat varsin toisenlaisia jos asiaa katsoo siitä näkökulmasta, että valtion lainsäädäntö "luo" pankkitoiminnan.

Kirjoittajien keskeinen analyysi pankkien identiteetin luomisesta lainsäädännöllä liittyy aikakauteen, jota kutsutaan usein "uusliberalistiseksi". Miksi nykyisenkaltaiset rahoitusmarkkinat syntyivät? Kirjoittajat kieltäytyvät analysoimasta tapahtunutta rahoitusmarkkinoiden vapauttamisen käsittein. Heidän mukaansa kyse oli pikemminkin valtiovallan tietoisesta pyrkimyksestä lisätä kilpailua rahoitussektorilla, ainakin rahoituskapitalismin ydinmaissa. 
Ennen 1990-lukua (Yhdysvaltoja lukuun ottamatta) yritysten oli rahaa lainatakseen asioitava pankin kanssa. Tilanne haluttiin muuttaa poliittisin päätöksin. Hallitukset olivat aloitteellisia kilpailun lisäämisessä rahoitussektorilla. Yritysten ja kotitalouksien lainamäärä kasvoi; laajemminkin luottokriteerit löystyivät. Hallitukset halusivat muuttaa kalliin pankkeihin pohjautuvan pääoman välitysjärjestelmän. Pankkien kun täytyy jakaa riskejään ja luoda infrastruktuuria luottokelpoisuuden varmistamiseksi. Tämä puolestaan aiheuttaa kustannuksia ja näkyy pääoman hinnassa.

Kilpailun lisääntymisen seuraukset olivat monenlaisia. Esimerkiksi investointipankkitoiminta ja "roskalainamarkkinat" laajenivat. Suurin siirtymä tapahtuu kirjoittajien mukaan kun pankeista tulee markkinatoimijoita auktoriteettien sijaan. Vanhassa järjestelmässä pankeilla oli todellista valtaa, jopa arvovaltaa. Kilpailua lisäämällä ajateltiin luotavan tehokkuusetuja markkinoille. Kilpailun lisääminen pakotti pankit kuitenkin etsimään voittoja uudella tavalla, koska ne menettivät keskeisen "välittäjän” roolinsa.

Välittäjän rooli tarkoittaa, että pankeilla on perinteisesti ollut erityinen asema rahoitusmarkkinoilla talletusten vastaanottajina ja lainojen myöntäjinä. Vaikka tästä roolista seurasikin yllämainittuja aikaperspektiivien yhteensovittamisen ongelmia, kyseessä oli pankkien aseman perusta. Kilpailun lisäämisen keskeinen vaikutus oli pankkien välittäjäaseman purkaminen (disintermediation). Tämän myötä pankkien perinteinen liiketoimintamalli ja auktoriteettiasema heikkenivät.

Välityksen purkaminen tapahtuu perinteisen pankkitoiminnan molemmilla puolilla, sekä talletuksissa että lainaamisessa. Sijoitusrahastot, jotka ohjaavat sijoittajien rahat suoraan arvopapereihin ja rahamarkkinoille, ovat kasvaneet talletuksia suuremmiksi. Lainaamisen painopiste on muuttunut samalla tavalla. Siinä missä pankkilainat olivat muutama vuosikymmen sitten yritysten keskeinen keino hankkia rahoitusta, tänä päivänä joukkovelkakirjat ovat yrityksille pankkilainoja merkittävämpi rahoituslähde. Vaikka nämä ilmiöt ovat kaikista näkyvimpiä Yhdysvalloissa, trendi on samanlainen koko läntisessä maailmassa.

Seuraus kaikesta tästä on arvattava. Joutuessaan luopumaan välittäjän roolistaan finanssimarkkinoilla, pankkien on keksittävä uusia liiketoiminnan muotoja esimerkiksi arvopaperistamisesta ja finanssi-innovaatioista. Pankit myös pyrkivät kasvamaan yritysostojen avulla säilyttääkseen kannattavuutensa. Kirjoittajat toteavatkin, että merkittävä osa amerikkalaisista ja 
eurooppalaisista jättipankeista näyttää "suurilta raskaasti vivutetuilta suojarahastoilta". Pankit ovat alkaneet muistuttamaan "varjopankkeja" pärjätäkseen kilpailussa.

Kirjoittajien huomioista seuraava pääväite on tavallaan triviaalisti totta, mutta samalla se on suorastaan raikas. Pankkien valta ei ole kasvanut, vaan vähentynyt. Ne harjoittavat innovaatiota ja arvopaperistamista ja toimivat raskaasti vivutettuina koska niillä ei ole niiden entistä asemaa. Ne joutuvat kilpailutilanteen pakottamina keksimään tällaisia uusia markkinoita, koska pankkina oleminen ei ole enää kovin kannattavaa.

Kirjoittajat huomauttavat osuvasti, että sääntelyjärjestelmiä ei ole kovin kiinnostavaa tutkia analysoimalla sääntelyn "määrää", vaikka toki keskeiset valvontaviranomaiset ovat olleet raskaasti aliresurssoituja. Sen sijaan olennaista ovat sääntelyn julkilausutut ja julkilausumattomat tavoitteet sekä keskeiset instituutiot.

Uusliberalismi ei luonnollisesti ole missään vaiheessa lopettanut rahoitusmarkkinoiden sääntelyä. Sääntelyn tavoitteet ovat kuitenkin muuttuneet - ja muuttuvat jatkuvasti. 1990-luvulta alkaen julkilausuttu tavoite oli, että sääntelyn tulisi olla pikemmin markkinoita tukevaa kuin niitä rajoittavaa. Sääntely rakennettiin tälle pohjalle. Baselin sopimus (Basel 1) oli kirjoittajien mielestä selkein "markkinaehtoisen sääntelyn" manifestaatio. Basel edusti myös "sääntelyn konvergenssia": sääntely yhdenmukaistui maiden välillä. Keskeisiä lähtökohtia tässä sääntelyregiimissä olivat "markkinat tietävät parhaiten" -periaate ja markkinoiden tekninen luonne. Tätä seurannut sopimus, "Basel 2" korosti itsesääntelyn merkitystä ja painotti pankkien omia riskianalyyseja reservivaatimusten pohjana. Myös luottoluokituslaitosten rooli kasvoi.

Itsesääntelystä tuli rahoitusmarkkinoilla keskeinen käsite. Tämän tuloksena pankeista tuli yhä suurempia, ja ne kehittivät esimerkiksi omia VaR -malleja riskiensä arvioimiseen. . Kyse oli stressitesteistä, joiden parametrit pankit päättivät itse. Poliitikkojen usko tällaisten riskianalyysimallien toimivuuteen oli vahva.

Finanssikriisi on luonnollisesti pakottanut päättäjät kehittämään uusia sääntelyideoita. Kirjassa käydäänkin läpi kolme keskeistä avausta ja pohditaan niiden ongelmia. Näitä ovat muutokset Basel-järjestelmässä ("Basel 3"), niin sanottu Volckerin sääntö sekä ehdotukset pankkien pilkkomiseksi. Basel 3 liittyy lähinnä pääomavarantojen lisäämiseen jotta systeemisten 
riskien ja niiden myötäsyklisten vaikutusten teho heikkenisi. Muutokset ovat kuitenkin pieniä eikä niillä sen kummemmin puututa itse pankkitoiminnan luonteeseen. Volckerin sääntö taas kieltää osan pankkien spekulatiivisista investoinneista ja rajoittaa esimerkiksi suojarahastoihin sijoittamista. Sääntö on suunniteltu ennen kaikkea välttämään tilanteita joissa pankit on pelastettava, eikä niinkään rauhoittamaan riskialtista finanssitoimintaa. Volckerin sääntö koskeekin ainoastaan talletuksia vastaanottavia laitoksia. Niinpä se on kirjoittajien mukaan hyvin puutteellinen, ja pelkästään Yhdysvalloissa voimassa olevana tätäkin enemmän.

Pankkien pilkkomista on usein ehdotettu ratkaisuna tilanteisiin, joissa pankkeja on pakko pelastaa (ja näitä tilanteita edeltäviin pyrkimyksiin saada kriisitilanteessa pelastettavan asema fuusioiden avulla). Monet ajattelevat myös, että talletukset pitäisi jotenkin "eristää" pankkien riskialttiimman toiminnan vaikutuksilta. Toisinaan pankkien pilkkomista esitetään myös kilpailutilanteen kehittämiseksi. Kirjoittajat suhtautuvat näihin esityksiin periaatteessa myötämielisesti. He kuitenkin huomauttavat ettei pankkien pilkkominen itsessään muuta pankkien toimintalogiikkaa ja edistä siirtymää spekulaatiosta investointien rahoittamiseen.

Eräs kirjan keskeisistä viesteistä (kiinnostavan analyysin ohella) on, että pankkien tulevaisuus on aidosti auki. Ensinnäkään rahoituskapitalismi ei kehity lineaarisesti tai deterministisesti. Toiseksi pankeilla on hyvin erilaisia mahdollisia rooleja. Lisäksi rahoitus ei ole maailmanlaajuisesti niin yhdenmukaista kuin voisi kuvitella. Tärkeä havainto on, että suurimmassa osasta kehitysmaita pankkitoiminta on edelleen muodoltaan "perinteistä". Itä-Aasian vahvoissa teollisuusmaissa sääntely on edelleen selkeämpää, ja esimerkiksi pääomakontrollien tai vaihtelevien reservivaatimusten kaltaisia välineitä ei ole hylätty. Oleellista onkin kysyä, lähdetäänkö näissä maissa luomaan "moderniksi" katsottua pankkijärjestelmää. Tällä on varmasti merkittävä vaikutus tulevaisuuden rahoituskriisien muotoon ja vaikutuksiin. Kuten kirjoittajat muistuttavat, finanssijärjestelmän kehittyneisyys ja pääoman liikkuvuus näyttävät lisäävän finanssikriisien esiintyvyyttä.

Kirjoittajat analysoivat myös tuttuja teemoja, kuten riskien hajauttamisen ja tosiasiallisen kasaamisen suhdetta arvopaperistamisprosessissa, sekä tehokkaiden markkinoiden hypoteesin ongelmia "menneisyyden tilastollisena heijastumana". Nämä ovat sinänsä mielenkiintoisia asioita, ja lisävät kirjan vahvuutta kriittisenä perusteoksena rahoituksesta yhteiskunnallisena 
toimintana.

Käsitteellisiä työkaluja rahoitustoiminnan analysointiin esitellään kiinnostavasti, mutta lukija odottaisi niiden kantavan pidemmälle. Kirjoittajat esimerkiksi jakavat pankkitoiminnan "synkroniseen" ja "diakroniseen". Ensimmäinen viittaa lyhyen tähtäimen ja nopeiden voittojen näkökulmaan, jälkimmäinen pitkäjänteisempään ja sosiaalisesti sitoutuneempaan toimintaan, jossa välitetään esimerkiksi tulevaisuuden investoinneista. Jaottelu on kiinnostava ja näyttää havainnollisesti pankkien erot. Sitä on kuitenkin hieman työlästä soveltaa kehikkoon, jossa ehdotetaan parempia konstitutiivisia sääntöjä pankkitoiminnalle. Analyysivälineet ovat hyödyllisiä, mutta niiden soveltaminen jää kirjassa kesken.

Tavoitellessaan "ohjelmallisempaa" tekstiä kirjoittajat jäävät tasolle, jossa todetaan että julkinen keskustelu on välttämätöntä, pankkien erilaisuus on tunnistettava, ja pankit voisivat yhtä hyvin olla luonteeltaan sosiaalisesti sitoutuneita ja investointeihin fokusoituneita. Tässä yhteydessä kiinnostavin on analogia lentokoneteollisuuteen, joka kirjoittajien mukaan osoittaa, ettei turvallisuuden ja kannattavuuden tarvitse olla ristiriidassa keskenään. Nämä ajatukset jäävät kuitenkin keskeneräisiksi. Toki voi kysyä, miten paljon yhdeltä kirjalta voi odottaa? The problem with banks on tällaisenaankin kiinnostava johdanto tärkeään aiheeseen.

\section{Kirjallisuus}

Rawls, J. 1955. Two concepts of rules. The Philosophical Review 64:1, 3-32.

Searle, J. 1969. Speech acts. An essay in the philosophy of language. Cambridge: Cambridge University Press. 